\title{
Storm Water Management Model Sensitivity to Different Design Storm Types and Parameters: The Case of Tangier Experimental Basin, Morocco
}

\author{
Hicham Bennani Baiti ${ }^{*}$, Ahmed Bouziane', Driss Ouazar'; and Moulay Driss Hasnaoui
}

' Laboratoire d'Analyse des Systèmes Hydrauliques LASH, Ecole Mohammedia d'Ingénieurs, Université Mohamed V, Avenue Ibn Sina, B.P. 765 Agdal, Rabat, Morocco; ${ }^{2}$ Direction de la Recherche et de la Planification de l'Eau, Ministère Délégué Auprès du Ministre de l'Energie, des Mines, de l'Eau et de l'Environnement Chargé de l'Eau, Rue Hassan Benchekroun, Agdal, Rabat, Morocco.

Received: March 5, 2015 / Accepted: February 16, 2017

\begin{abstract}
Rainfall records with time steps less than $15 \mathrm{~min}$, which are required for designing storm water sewerage in urban areas, are rarely available throughout the Moroccan territory. The study was conducted with the objective to tackle this problem through the use of design storm structures with time steps that vary from 5 to $15 \mathrm{~min}$. For this purpose, we used two structural families of design storms: (i) design storms derived from Intensity-Duration-Frequency (IDF) curves of Chicago, Composite, Desbordes, Watt, Weibull, Uniform, and Triangular design storm types; (ii) design storms from the Soil Conservation Service (SCS) synthetic rainfall. The selected design storm structures are those adapted to the rainfall distribution of Tangiers experimental basin and their resulted peak flows are comparable to the flow generated using the synthetic rainfall events. We also did sensitivity analysis for the Storm Water Management Model (SWMM) to changes of different design storm structural parameters, which includes storm duration, time steps, and intensity peak position. We evaluated how changes on these parameters affect peak flows and runoff volumes. In addition, Principal Component Analysis (PCA) method was used to validate the sensitivity analysis by identifying key storm parameters that significantly affect peak flows and Runoff volumes. SWMM model calibration results showed that the Desbordres and Chicago structures best fitted observed flow. Moreover, comparison of different SCS synthetic rainfall forms to observed rainfall events retains that of type 1. Furthermore, the Weibull and watt storms have both a shape parameter that has been calibrated by using the observed events. Overall, simulation results confirmed that peak flow was greatly affected by design storm structures, but was not closely correlated with rainfall intensity.

Keywords: Design rainfall, SWMM, sensitivity analysis.
\end{abstract}

*Corresponding author: hb_bennani@yahoo.fr

\section{Introduction}

This work has been done in response to the recommendations of the Director National Plan of sewerage sanitation in Morocco (ONEP, 1998). This scheme advocates the need for choice and equipment of experimental basins for the use and calibration of rainfall-runoff models of the determination peak flows and runoff volumes required for the design of storm drainage structures. In this context, an agreement has been reached between the "Office National de distribution d'électricité et d'eau potable" and "Ecole Mohammedia d'ingénieurs" for the selection and equipment of experimental basins in Morocco (Bouziane and Bennani Baiti, 2013). Indeed, various sewerage sector stakeholders in Morocco (local engineering firms and concession of sanitation networks) have faced difficulties in the use of rainfallrunoff models. These models require large number of input parameters and variables, which make it difficult to use compared to empirical methods such as Caquot currently used in Morocco. While, the Caquot method is simple to use, it has some limitations. It is applicable only for small areas ( $<200 \mathrm{ha})$ and high runoff coefficients ( $>20 \%$ ) (Bourrier, 1981). Using this method in areas with features outside these limits would lead to either over estimation peak flows and thereby size of rainwater conduits, which will lead to additional investment costs.

To achieve this, we proposed to use the Storm Water Management Model for analyzing complex and interdependent hydrologic parameters (e.g., infiltration, depression storage, terrain roughness, etc...). So, the aim of this work is to facilitate the use of SWMM model by targeting the most sensitive model parameters and its calibration using observed rainfall-runoff event.

We used rainfall-runoff data recorded at the Tangier's experimental basin. Model calibration results will help various stakeholders in the sewerage sector to:

(i) Choose model calibration parameters that affect the 
peak flow hydrograph. This part was the subject of a first publication related to the study of SWMM model parameters sensitivity. This part is covered in (Bennani Baiti et al., 2017).

(ii) Tackle the lack of rainfall records with time steps of less than 15 minutes, required for the design of storm water sewerage in urban areas, throughout the entire Moroccan territory. This problem was addressed by using design storm structures with time steps that vary from 5-15 min. These design storm structures were selected because they adapt to the rainfall distribution of Tangier's experimental basin and resulted peak flows comparable to the flow generated using the synthetic rainfall events for the basin. This is the main focus of this paper.

(iii) Choose calibration parameters for different infiltration functions used by SWMM model according to the observed events in Tangier's experimental basin (under preparation).

In this article, we dealt with the second point related to design storms, commonly used in rainfall-runoff modeling. The design storms used in this study include those derived from the IDF curves and SCS type synthetic rainfall. The first group of the design rainfall includes Chicago rainfall (Keifer and Chu, 1957), composite storm (Musy and Higy, 1998), Desbordes storms (Chocat, 1997), Watt rainfall (Watt et al., 1986), Weibull rainfall (Hager, 1988), the uniform rain (Mitci, 1974) and triangular rainfall. While the second group includes the SCS type synthetic rainfall (SCS, 1986).

Several studies have been conducted in different parts of the world to determine design storms. Keifer and Chu (1957) suggested a synthetic rainfall intensity pattern for Chicago sewerage system design. Huff (1967) developed rainfall distribution formulations in terms of time based on severe storms in Illinois. Pilgrim and Cordery (1975) suggested a hyetograph analysis method based on the classification of rows in each storm and determining a structure based on the average of the ranks. Similarly, certain types of design rainfall are generally used for the design systems of agricultural drainage basins or mixed urban and agricultural basins. Hoang (1987) proposed a design rainfall with a total duration of 5 days, based on the statistical analysis of daily rainfall data. Likewise, Dang (1999) applied a hyetograph of a 5-day storm duration. Similarly, Thang (2005) proposed a rainfall model with a distribution based on the analysis of hourly events in Hanoi city.

The selected design storm structures in this article are those adapted to the rainfall distribution of Tangiers experimental basin and their resulted peak flows are comparable to the flow generated using the synthetic rainfall events.

\section{Materials and Methods}

\subsection{Methodology}

The first part of this study compared the structures of different types of design storms (form and maximum intensity) through the peak flows and runoff volumes resulting from the SWMM model. Then, we analyzed the SWMM model sensitivity (Version
5.0.022) to several design rainfall parameters pertinent to each storm structure (e.g., storm duration, time step, and position of peak hyetograph). The sensitivity tests have been carried out for different return periods $(T=5,10,20,50$, and 100 years, see Figures 2, 4 -7, 9-10, 12-13). These return periods were used for the design of storm water sewerage in Morocco (ONEP, 1998); and includes:

(i) Storm water sewerage in urban areas (2 years for tertiary collectors, 5 years for secondary collectors, and 10 years for primary collectors)

(ii) Storm water collection network in extra-urban areas and road works $(20,50$, and 100 years)

Sensitivity analysis results will help identify the storm parameters for each design storm types that significantly affect peak flows and runoff volumes.

Then, we selected design storms derived from the IDF curves, which make it possible to generate peak flows comparable to those calculated by the synthetic structure of the average rainfall. This synthetic structure was determined on the basis of the rainfall events observed in Tangiers experimental basin. The synthetic structure of the average rainfall was also used to select the SCS storms representing the rainfall distribution of the study area. The calibration of design storm structures using empirical parameters, which give peak flows values with a significant difference compared to the average synthetic rainfall, is necessary to adapt these design rainfall structures to the study area.

Furthermore, sensitivity analysis results were checked for consistency using the Principal Component Analysis (PCA) method, a descriptive multivariate analysis that allows the description of a group of individuals with a set of quantitative variables. It establishes a resemblance record between individuals and is used to study the relationship between variables (Corinne Hahn, Sandrine Macé, 2012).

In our case study, the CPA method was used to validate the results of the sensitivity analysis of peak flow and runoff volumes to Design storm parameters. This method allows generating a component matrix which shows the correlation between the Design storm parameters, the peak flows and the extracted components. The importance of correlation between the Design storm parameters and the major component reveals information about the degree of impact of these parameters on the resulting peak flows and runoff volumes.

The calibration of the model is discussed in detail in (Bennani Baiti et al., 2017). This calibration identifies the parameters that significantly influence peak flows because the model uses a large number of parameters. The calibration was performed manually according to the events observed in the Tangier's experimental basin. This basin was used as a unique entity in the SWMM model. The SWMM model parameters values adopted are summed up in Table 1.

The Horton loss function (Mitci, 1974) for a loam soil type was used.

$$
F(t)=F_{c}+(F 0-F c) e^{-\alpha t}
$$

With model parameter values of:

- $F(t)$ is the Infiltration rate at time $t(\mathrm{~mm} / \mathrm{h})$

- $F c$ is ultimate infiltration rate $(\mathrm{mm} / \mathrm{h}): 76.2$

- FO is initial infiltration rate $(\mathrm{mm} / \mathrm{h}): 3.302$ 
- $\alpha$ is the decay constant (h-1): 4.5

\subsection{Study Area and Data}

Selection of the study area was determined by the existence of Tangier's experimental basin located in Northern Morocco. In 1990, this basin was equipped with Direction de la Région hydraulique du Loukous in collaboration with Régie Autonome de distribution d'eau et d'électricité de Tanger (RAID) (Rakik and Eijelouli, 1994). However, data collection and follow up in this experimental basin was suspended in 1993. The characteristics of the experimental basin are summarized as follows (Table 2).

Rainfall and runoff data for the experimental basin of Tangiers were presented by Rakik and Ejielouli (1994). The reports cover eight rainfall-runoff events recorded between September 1990 and December 1991. The storms selected are those with a total rainfall amount greater than $4 \mathrm{~mm}$, which is generally considered as sufficient to cause runoff in the sewerage system. This threshold of $4 \mathrm{~mm}$ was determined on the basis of hydrographs generated from rainfall events observed in the Tangiers experimental basin, which losses all the rainfall greater than 4 $\mathrm{mm}$ (Rakik and Ejielouli , 1994). The IDF curves used are from the city of Tangiers for the period 1940-2001 from the INGEMA (2001) report. IDF curves allowed us to have the Montana coefficients for different return periods presented in the table 3.

The intensity of rainfall with return period $T$ and duration $d$ can be described using a Montana formula (Meylan et al., 2012):

$$
\begin{aligned}
& \qquad I(T, d)=a(T) d^{-b(T)} \\
& I(T, d)=\text { intensity of rainfall }(\mathrm{mm} / \mathrm{h}) \\
& d=\text { duration of rainfall (hours) } \\
& a(T) \text { and } b(T)=\text { Montana coefficients with return period } T
\end{aligned}
$$

Table 1. SWMM model parameters values (source: Bennani Baiti et al., 2017).

\begin{tabular}{ll}
\hline Parameters & Values \\
\hline Depression storage & \\
pervious area $(\mathrm{mm})$ & 1.27 \\
impervious area $(\mathrm{mm})$ & 7.62 \\
Manning coefficient & \\
pervious area & 0.011 \\
impervious area & 0.17 \\
Drainage width $(\mathrm{m})$ & 906 \\
Impermeability coefficient $\mathrm{C}_{\text {imp }}(\%)$ & 37 \\
\hline
\end{tabular}

Table 2. Summary of Tangier experimental basin's characteristics (source: Bennani Baiti et al., 2017).

\begin{tabular}{lc}
\hline Parameters & Value \\
\hline Area $(\mathrm{ha})$ & 226 \\
Length $(\mathrm{m})$ & 2660 \\
Weighted average slope $(\%)$ & 1.23 \\
Area of the zone in progress urbanization $(\mathrm{ha})$ & 69 \\
Area of urbanized zone $(\mathrm{ha})$ & 157 \\
Gravelius Compactness coefficient & 1.28 \\
Length of the equivalent rectangle (km) & 2.5 \\
Width of the equivalent rectangle $(\mathrm{km})$ & 0.9 \\
Impermeability Coefficient $(\%)$ & 37 \\
\hline
\end{tabular}

Table 3. Montana coefficients for different return periods of the Tangiers city.

\begin{tabular}{ccc}
\hline $\mathbf{T}$ & $\mathbf{a}(\mathbf{m m} / \mathbf{h})$ & $\mathbf{b}$ \\
\hline $\mathbf{5}$ & 285.18 & 0.526 \\
$\mathbf{1 0}$ & 316.74 & 0.5 \\
$\mathbf{2 0}$ & 350.64 & 0.484 \\
$\mathbf{5 0}$ & 396.84 & 0.471 \\
$\mathbf{1 0 0}$ & 432.42 & 0.464 \\
\hline
\end{tabular}

\subsection{Presentation of Design Rainfall Structures Used}

Equations of design storms structures used in this study are summarized in Table 4.

\section{Results and Discussion}

\subsection{Comparison of Design Rainfall Structures}

Design rainfall structures are characterized by their maximum intensities. The return period of 100 years has been used as an illustration for the comparison of maximum intensities of design storm to visualize the deviations of these intensities for the greater pluviograph events frequency. This comparison is shown in Figure 1 below. Design rainfalls have been established with storm duration of $120 \mathrm{~min}$, a time step of $5 \mathrm{~min}$, and a peak position in the middle of the rainfall structure. Weibull intensity rainfall increases along with the significance of the " $n$ " form factor (Figure 1). However, the maximum intensities of Chicago, Composite and Desbordes structures are equivalent. Watt structure generates a maximum intensity that is classified behind those above followed by the triangular rainfall intensity. The maximum intensity within the uniform structure is the weakest.

Simulation results of SWMM model sensitivity to the types of design storm structures based on the peak flows and hydrographs volumes generated for the different return periods ( $\mathrm{T}=$ $5,10,20,50$, and 100 years) are shown in Figures 2 and 3 . The design peak flows (Figure 2) are not necessarily affected by the maximum intensity value of the design storm, but rather by their structures. Peak flow calculated based on Weibull structure $(n=30)$ for the various return periods were greater than those calculated using the structures of Chicago, Composite, and Desbordes.

Furthermore, the peak flows from Watt structure were greater than the flows calculated based on the Chicago, Composite, and Desbordes structures, which have intensities greater than that of the Watt structure. In addition, the magnitude of the peak flows calculated based on the triangular and uniform structures was dependent on the significance of the maximum intensities. The above results confirm the influence of the design rainfall structure on the flows generated by the SWMM rainfall-runoff model.

Contrary to peak flows, the runoff volumes have not been influenced by the choice of the rainfall type (Figure 3 ).

The SWMM model sensitivity analysis based on the parameters structuring the various design storms seems necessary. The parameters include the storm duration, time step, and the peak 
Table 4. Characteristics of Design storms used.

\begin{tabular}{|c|c|c|}
\hline Design structure & Equation & Parameters \\
\hline $\begin{array}{c}\text { Uniform } \\
\text { (Mitci, 1974) }\end{array}$ & $i(t)=a \times t d^{b}=$ Cste & $\begin{array}{l}t d: \text { storm duration }(\mathrm{min}) \\
i(t): \text { constant average intensity }(\mathrm{mm} / \mathrm{h}) \\
a \text { and } b \text { : parameters of the Montana formula }\end{array}$ \\
\hline $\begin{array}{c}\text { Triangular } \\
\text { (Yen and Chow), } \\
1980)\end{array}$ & $\begin{array}{l}0 \leq \mathrm{t}<\mathrm{tp} \rightarrow \mathrm{i}(\mathrm{t})=\frac{\mathrm{ip}}{\mathrm{tp}} \cdot \mathrm{t} \\
\qquad \mathrm{tp} \leq \mathrm{t}<\mathrm{td} \rightarrow \mathrm{i}(\mathrm{t})=\mathrm{ip}-\left[\left(\frac{\mathrm{ip}}{\mathrm{td}-\mathrm{tp}}\right) \cdot(\mathbf{t}-\mathrm{tp})\right] \\
\text { With : ip }=2 \cdot \mathrm{im}, \mathrm{im}=\mathrm{a} \cdot \mathrm{td}^{\mathrm{b}}\end{array}$ & $\begin{array}{l}\text { ip: peak intensity }(\mathrm{mm} / \mathrm{min}) \\
\text { i } \mathrm{m} \text { : mean intensity }(\mathrm{mm} / \mathrm{min}) \\
\text { td: storm duration }(\mathrm{min}) . \\
\text { tp: peak time }(\mathrm{min}) \\
\text { tp = r.td } \\
\text { r: peak position } \\
\text { a and b : parameters of the Montana formula }\end{array}$ \\
\hline $\begin{array}{c}\text { Desbordes } \\
\text { (Chocat, 1997) }\end{array}$ & $\begin{array}{r}0 \leq \mathrm{t}<t 1 \rightarrow \mathrm{i}(\mathrm{t})=\frac{\mathrm{i}_{1}}{\mathrm{t}_{1}} \cdot \mathrm{t} \\
\mathrm{t} 1 \leq \mathrm{t}<\mathrm{tp} \rightarrow \mathrm{i}(\mathrm{t})=\mathrm{i}_{1}+\left[\left(\frac{\mathrm{i}_{\mathrm{p}}-\mathrm{i}_{1}}{\mathrm{t}_{\mathrm{p}}-\mathrm{t}_{1}}\right) \cdot\left(\mathrm{t}-\mathrm{t}_{1}\right)\right] \\
\mathrm{tp} \leq \mathrm{t}<t 2 \rightarrow \mathrm{i}(\mathrm{t})=\mathrm{i}_{\mathrm{p}}-\left[\left(\frac{\mathrm{i}_{\mathrm{p}}-\mathrm{i}_{2}}{\mathrm{t}_{2}-\mathrm{t}_{\mathrm{p}}}\right) \cdot\left(\mathrm{t}-\mathrm{t}_{\mathrm{p}}\right)\right] \\
\mathrm{t} 2 \leq \mathrm{t}<t d \rightarrow \mathrm{i}(\mathrm{t})=\mathrm{i}_{2}-\left[\left(\frac{\mathrm{i}_{2}}{\mathrm{t}_{\mathrm{d}}-\mathrm{t}_{2}}\right) \cdot\left(\mathrm{t}-\mathrm{t}_{2}\right)\right] \\
\text { Avec }: d_{\text {intense }}=0,5 \cdot K \quad, t_{1}=2,25 \cdot K, t_{d}=5 \cdot K \\
t_{p}=t_{1}+0.5 d_{\text {intense }}, t_{2}=t_{p}+0 \cdot 5 d_{\text {intense }} \\
i_{1}=i_{2}=(0,25 \cdot K)^{b} \cdot \frac{\left(1-0,1^{1+b}\right)}{0,9 \cdot 0,1^{b}} \cdot 120 \cdot a \cdot 2^{b} \\
\mathrm{i}_{\mathrm{p}}=(0,25 \cdot \mathrm{K})^{\mathrm{b}} \cdot \frac{\left(0,1^{\mathrm{b}}-1\right)}{0.9 \cdot 0 \cdot 1^{\mathrm{b}}} \cdot 120 \cdot \mathrm{a} \cdot 2^{\mathrm{b}}\end{array}$ & 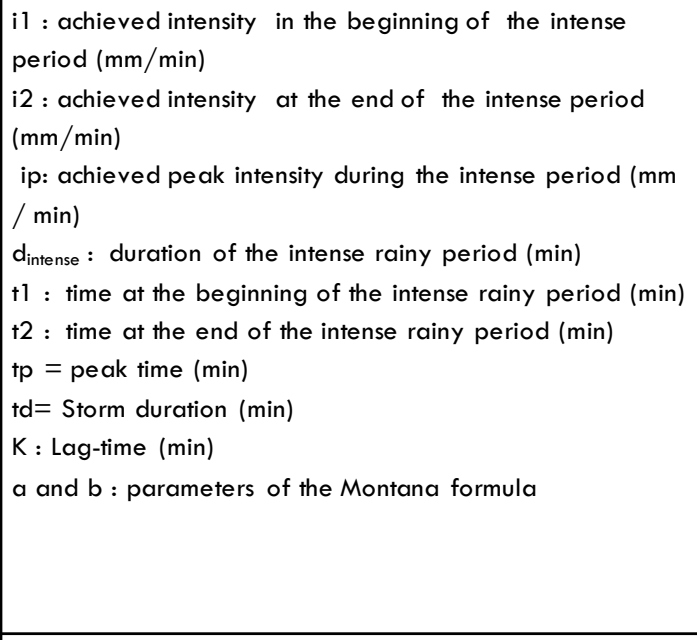 \\
\hline $\begin{array}{c}\text { Composite } \\
\text { (Musy and Higy, } \\
\text { 1998) }\end{array}$ & $\begin{array}{l}\qquad i\left(t_{j}\right)=a \cdot\left(\frac{t_{j}{ }^{b+1}-t_{j-1} b+1}{\Delta t}\right), j=1 \text { to } n \\
\text { avec } n=\frac{t d}{\Delta t} \text { et } t_{0}=0 \\
\text { ip }=\max (i(t i)), i=1 \text { to } n ; t p=r . t d\end{array}$ & $\begin{array}{l}\Delta t: \text { time step }(\mathrm{min}) \\
\mathrm{td}: \text { storm duration }(\mathrm{min}) \\
\mathrm{tp}=\text { peak time }(\mathrm{min}) \\
\mathrm{r}: \text { peak position } \\
\text { ip: peak intensity }(\mathrm{mm} / \mathrm{min}) \\
\mathrm{a} \text { and } \mathrm{b}: \text { parameters of the Montana formula }\end{array}$ \\
\hline $\begin{array}{c}\text { Chicago } \\
\text { (Keifer and Chu, } \\
\text { 1957) }\end{array}$ & $\begin{aligned} i & =a \cdot(1+b)(t d)^{b} \\
i a & =a \cdot(1+b)\left(\frac{t_{a}}{1-r}\right)^{b} \\
i b & =a \cdot(1+b)\left(\frac{t_{b}}{r}\right)^{b} \\
\mathrm{ip} & =\mathrm{a} \cdot \Delta \mathrm{t}^{b} \\
\mathrm{td} & =\mathrm{tb}+\mathrm{ta} ; \mathrm{tb}=\mathrm{r} \cdot \mathrm{td} ; \mathrm{ta}=(1-\mathrm{r}) \cdot \mathrm{td} ;\end{aligned}$ & $\begin{array}{l}\text { ia: intensity after the peak }(\mathrm{mm} / \mathrm{min}) \\
\text { ib: intensity before the peak }(\mathrm{mm} / \mathrm{min}) \\
\text { ip: peak intensity ( } \mathrm{mm} / \mathrm{min}) \\
\text { td : storm duration ( } \mathrm{min}) \\
\text { tb: time before the peak intensity } \\
\text { ta: the time after the peak intensity } \\
\Delta t=\text { time step; } r \text { : peak position } \\
a \text { and b : parameters of the Montana formula }\end{array}$ \\
\hline $\begin{array}{c}\text { Weibull } \\
\text { (Hager and } \\
\text { Sinniger, 1988) }\end{array}$ & $\begin{aligned} i(t)=i p \cdot\left(\frac{t}{t p} e^{\left(1-\frac{t}{t p}\right)}\right)^{n} \\
i m=\frac{i m \cdot n^{n+1}}{r e^{n} n !}\end{aligned}$ & $\begin{array}{l}\mathrm{n} \text { : form factor }(1,3,5,10,30,50 \text {, and } 100) \\
\text { ip: peak intensity }(\mathrm{mm} / \mathrm{min}) \\
\text { tp: peak time ( } \mathrm{min}) \\
\text { td : storm duration }(\mathrm{min}), \\
\mathrm{r} \text { : peak position } \\
\text { im: mean intensity ( } \mathrm{mm} / \mathrm{min} \text { ) } \\
\mathrm{a} \text { and b : parameters of the Montana formula }\end{array}$ \\
\hline $\begin{array}{l}\text { WATT } \\
\text { (Watt et al., } \\
1986)\end{array}$ & $\begin{array}{l}0 \leq \mathrm{t}<t p \quad \rightarrow \mathrm{i}(\mathrm{t})=\frac{\mathrm{ip}}{\mathrm{tp}} \cdot \mathrm{t} \\
\mathrm{rtd} \leq \mathrm{t}<t d \rightarrow \mathrm{i}(\mathrm{t})=\mathrm{ip} \cdot \mathrm{e}^{-\mathrm{K}\left(\frac{\mathrm{t}-\mathrm{tp}}{\mathrm{td}-\mathrm{tp}}\right)} \\
\text { Avec: } i \mathrm{p}=\frac{\mathrm{H}}{\left(\frac{\mathrm{t}}{2}+\frac{\mathrm{td}-\mathrm{tp}}{\mathrm{K}}\right)}, \mathrm{H}=\mathrm{a} \cdot \mathrm{td}^{\mathrm{b}+1} ; \mathrm{tp}=\mathrm{r} . \mathrm{td}\end{array}$ & $\begin{array}{l}\text { ip = peak intensity }(\mathrm{mm} / \mathrm{min}) \\
\mathrm{H}: \text { Total precipitation Height }(\mathrm{mm}) \\
\text { tp = peak time }(\mathrm{min}) \\
\mathrm{td}=\text { storm duration }(\mathrm{min}) \\
\mathrm{K}=\text { decay coefficient } \\
\mathrm{r}: \text { peak position } \\
\mathrm{a} \text { and } \mathrm{b}: \text { parameters of the Montana formula }\end{array}$ \\
\hline $\begin{array}{l}\quad \text { SCS } \\
\text { (Soil } \\
\text { Conservation } \\
\text { Service, 1986) }\end{array}$ & Four SCS types rainfall distribution of 6 and $24 \mathrm{~h}$ & $\begin{array}{l}\text { SCS rainfall coefficients were adopted from Chow et al. } \\
\text { (1988) }\end{array}$ \\
\hline
\end{tabular}


position.

\subsection{Impact of Variations of Design storm parameters on the Peak Flows and Runoff Volumes}

\subsubsection{Storm Duration}

We have considered a reference storm duration equivalent to the concentration time in the Tangiers experimental basin. It was obtained by calculating the average time between the end of net rainfall and the end of runoff from the observed events. The concentration time was 60 minutes. There are also empirical formulas for determining the concentration time (ADM, 2008). The various formulas considered rely on:

- The length and of the watershed slope(Kirpich, California, US-corps, Spanish - Vante Chow);

- The area and of the watershed slope (Ventura)

- The length, area and the watershed slope (Passini, Giandotti, Turraza).

The calculation of the time of concentration using different formulas cited above shows that the VanTechow formula best approaches the average observed concentration time (Figure 4).

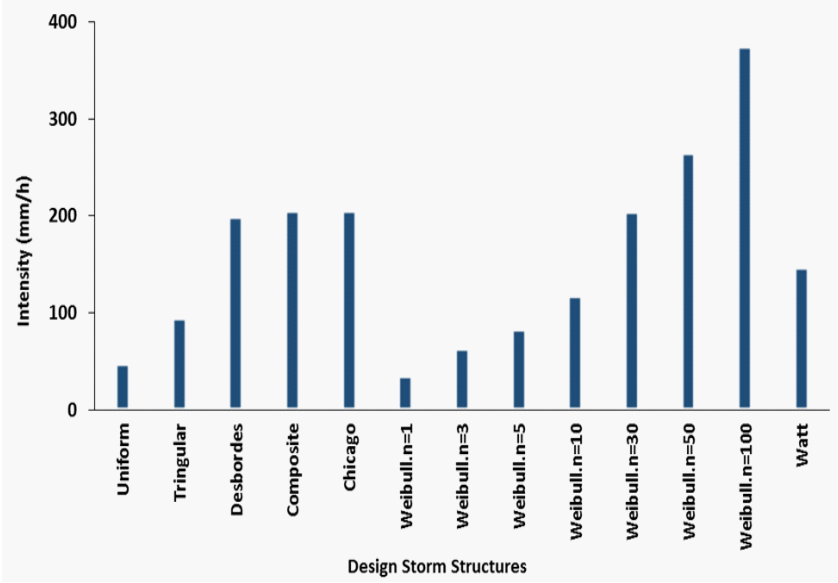

Figure 1. Comparison of maximum intensities for various types of Design storm.

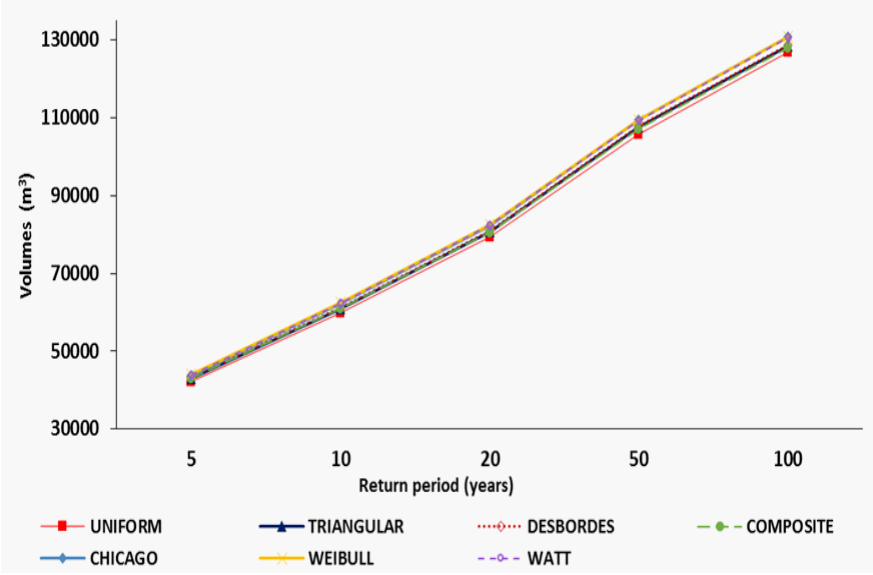

Figure 3. Comparison of runoff volumes from the different types of the design storm.
The sensitivity study of this parameter is based on the variation of the storm duration from $-50 \%$ to $+200 \%$ of the reference values of the concentration time. The ascending variation results from the storm duration of the observed recorded events (average duration $=120 \mathrm{~min}$, maximum duration $135 \mathrm{~min}$ ).

The design rainfall structures from the variation of the storm duration revealed that apart from the Chicago and Composite structures whose intensities remain constant, the intensities of other rainfall structures decrease with an increasing storm duration. The Relative deviations of peak flows for a variation of the storm duration compared to the reference value are presented in Figure 5.

From the Figure $5 \mathrm{~A}$, a decrease of $-50 \%$ of the storm duration was observed compared to the reference value that resulted to:

- An increase of $+10 \%$ of peak flows using uniform rainfall. a decrease of peak flows of $-25 \%$ for Weibull and Composite rainfalls, of $-15 \%$ for Chicago structure and $-10 \%$ for Desbordes structure.

- No impact on the resulting peak flows for the Watt and Triangular structures

- The increase of the storm duration (Figures 5B, 5C \& 5D) beyond the reference duration causes:

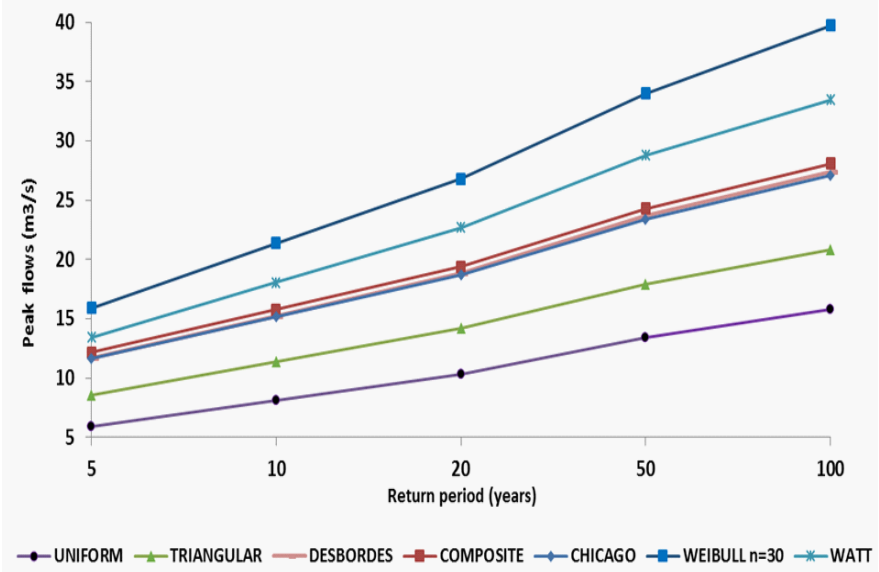

Figure 2. Comparison of peak flows from the different types of the design storm.

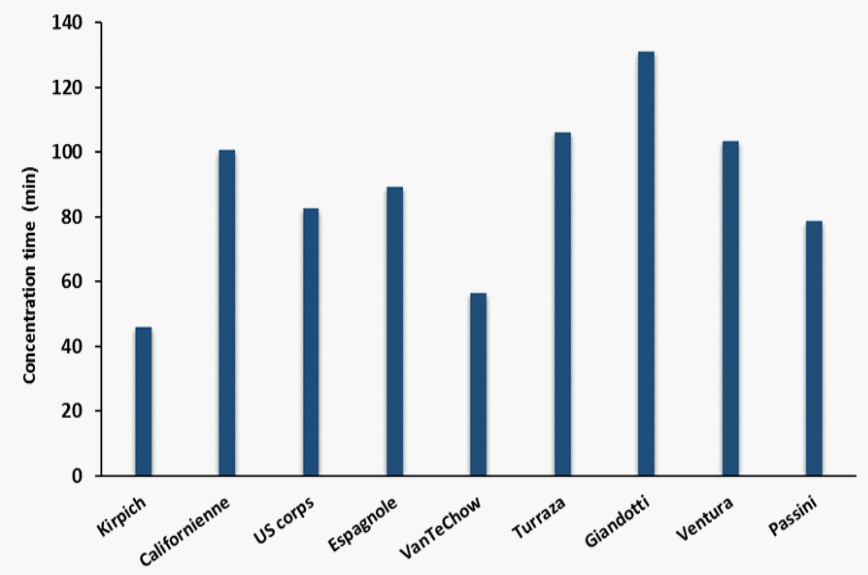

Figure 4. Calculation of concentration time by different empirical formulas. 

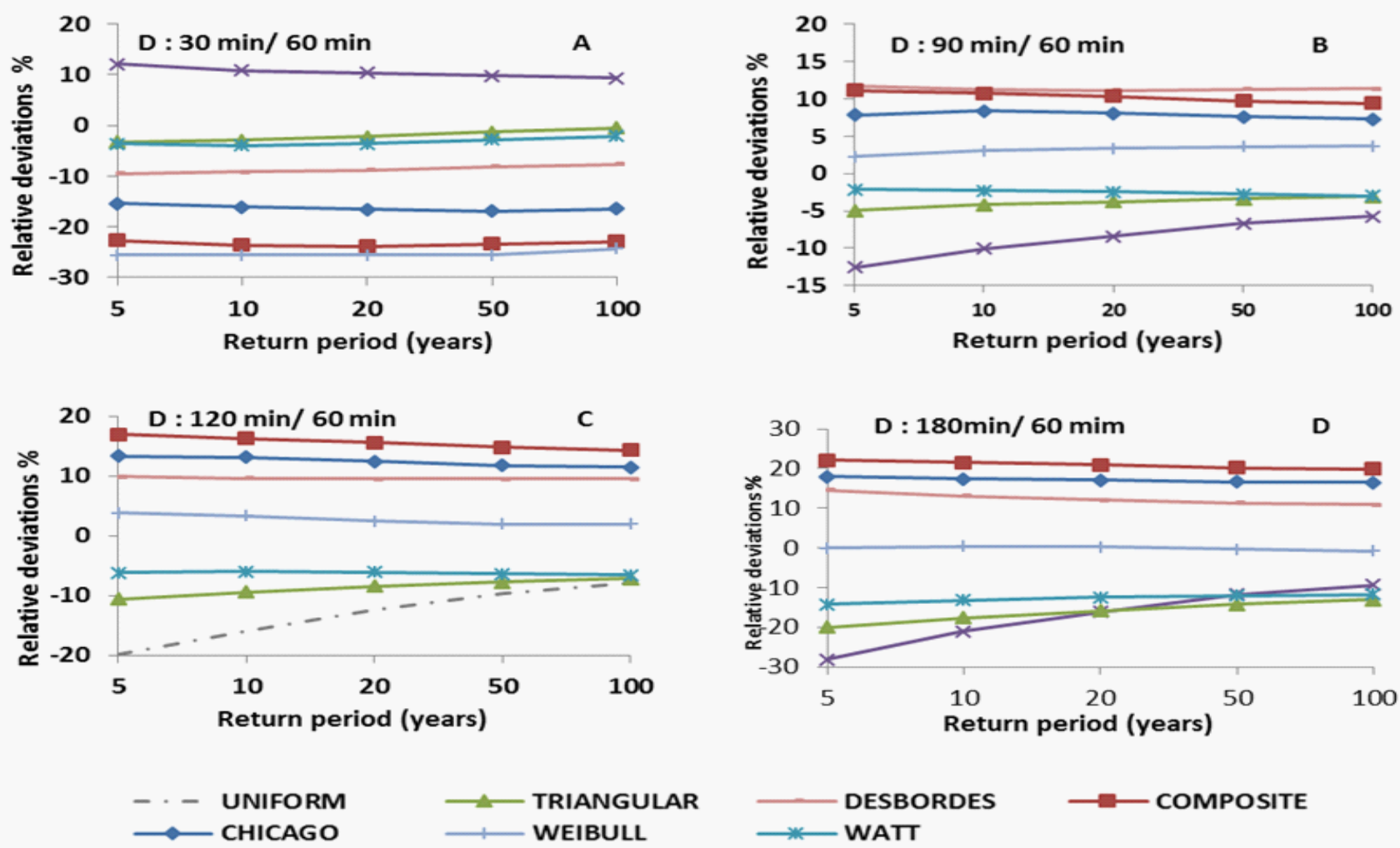

Figure 5. Relative deviations of peak flows for a variation of the storm duration of $-50 \%$ ( $A: 30 \mathrm{~min})$, of $+50 \%$ (B: $90 \mathrm{~min})$, of $+100 \%$ (C: $120 \mathrm{~min}$ ) and of $+200 \%$ (D: $180 \mathrm{~min}$ ) compared to the reference value (60min).

- An increase between $10 \%$ and $15 \%$ of peak flows generated by Chicago and Composite structures for a variation of $+100 \%$ of the reference storm duration (equivalent to the average duration of the observed recorded hyetograph) (Figure 5C). An increase of $10 \%$ of peak flows calculated using Desbordes structure for a variation of $+50 \%$ of the reference storm duration (Figure 5B). This difference becomes constant (10\%) for an increase from $50 \%$ to $200 \%$ of the storm duration (Figures 5B, 5C \& 5D).

- A minor increase of peak flows calculated (less than $3 \%$ ) from the Weibull structure for a variation of reference storm duration from $+50 \%$ to $+200 \%$. (Figures 5B, 5C \& 5D).

- A decrease of peak flows from - $12 \%$ to $-30 \%$ for a 5 year return period for a variation of reference storm duration from $+50 \%$ to $+200 \%$ at the level of uniform rainfall (Figures $5 B, 5 C \& 5 D)$. It is also noticed that these peak flow variations decrease with the increase of return periods.

A decrease of the generated peak flows of $-5 \%$ based on the Watt structure and of $-10 \%$ based on Triangular structure for a storm duration equivalent to the average duration of observed hyetograph (+100\% of the reference duration) (Figure $5 \mathrm{C})$.

The Relative deviations of runoff volumes for a variation of the storm duration compared to the reference value are presented in Figure 6 below. The storm duration is the sole parameter that significantly influences the hydrographs volumes. The volumes generated from the Uniform, Triangular, Desbordes, Composite and Weibull Design Storms are identical and follow the same trend according to the variation of return period and the rainfall duration.

For a decreasing of $50 \%$ of storm duration compared to the reference duration (Figure 6A), the volumes generated from the rainfall structures go down by increasing the return period of $25 \%$ to $-43 \%$.

For a rise of $50 \%, 100 \%$ and $200 \%$ of the storm duration to the reference value (Figures 6B, 6C \& 6D), the volumes generated from the rainfall structures go up according to the increase of the return period of:

- From $25 \%$ to $36 \%$ for an increase of $50 \%$, from $50 \%$ to $68 \%$ for an increase of $100 \%$, and from $98 \%$ to $126 \%$ for an increase of $200 \%$ according to the Watt and Chicago rainfalls.

- From $27 \%$ to $38 \%$ for an increase of $50 \%$, from $52 \%$ to $73 \%$ for an increase of $100 \%$, and from of $97 \%$ to $133 \%$ for an increase of $200 \%$ according to the Uniform, Triangular, Desbordes, Composite and Weibull rainfall structures.

\subsubsection{Time increment Step}

The reference time step adopted was fixed according to those of the observed events of our experimental basin. This taken time step is equivalent to $5 \mathrm{~min}$. 

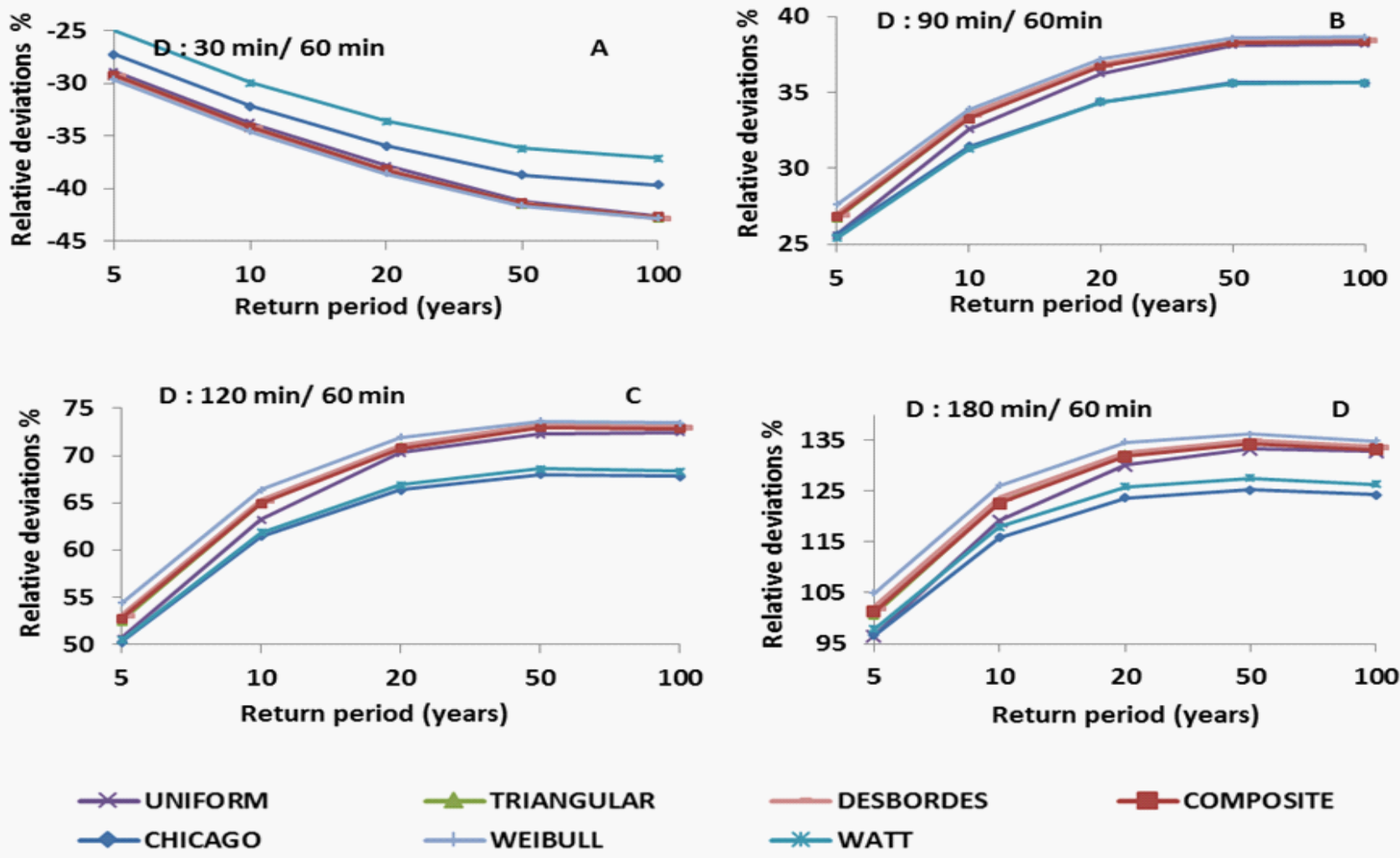

COMPOSITE

Figure 6. Relative deviations of runoff volumes for a variation of the storm duration of $-50 \%$ (A: $30 \mathrm{~min})$, of $+50 \%$ (B: $90 \mathrm{~min}$ ), of $+100 \%$ (C: $120 \mathrm{~min}$ ) and of $+200 \%$ (D: $180 \mathrm{~min}$ ) compared to the reference value (60 $\mathrm{min}$ ).
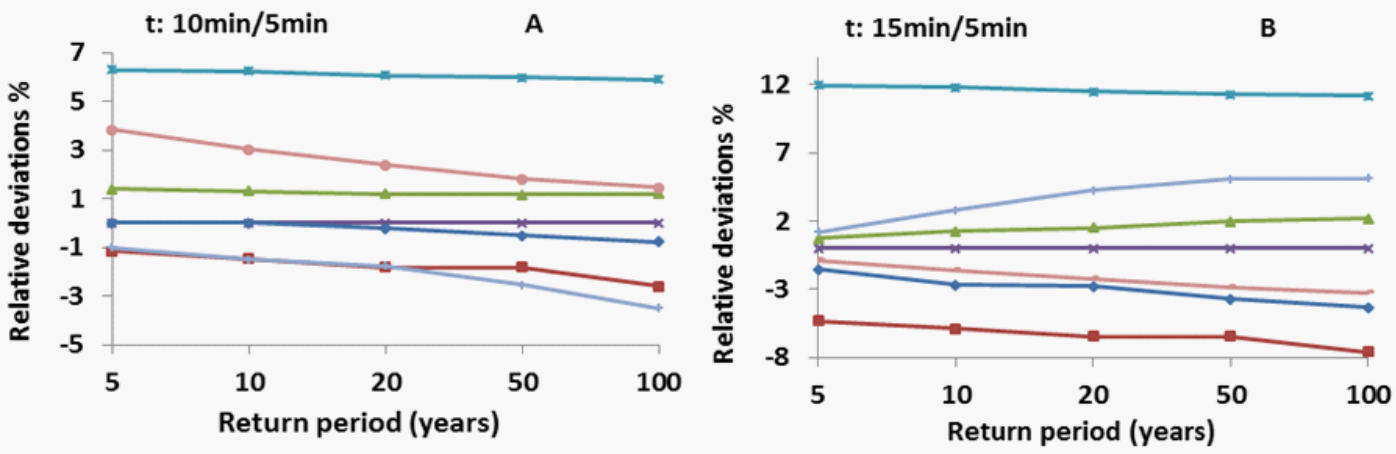

$\because$ UNIFORM $\multimap$ TRIANGULAR $\longrightarrow$ DESBORDES - -COMPOSITE $\multimap$ CHICAGO $\longrightarrow$ WEIBULL $\rightarrow$ WATT

Figure 7. Relative deviations of peak flows for a variation of $+100 \%$ (A: $10 \mathrm{~min}$ ) and of $+200 \%$ (B: 15 $\mathrm{min}$ ) of time step reference (5 $\mathrm{min})$.

The other time steps used for rainfall data analysis were 10 $\min$ and $15 \mathrm{~min}$. This represents a variation of $100 \%$ and $200 \%$ of the reference value, respectively. The study of the rainfall structures showed that the maximum intensities of the Composite and Chicago structures decrease with an increase of the time step. However, the intensities of the other design storms remain constant.

The relative deviations of peak flows and runoff volumes for a variation of time step reference are illustrated in the following figures (Figures $7 \& 8$ ). From the figure 7 , we notice that the increase of the time step:

- Generates an increase of the peak flows $16 \%$ for a time step of $10 \mathrm{~min}$ (Figure 7A) and $12 \%$ for a time step of 15 min (Figure 7B) according to the Watt rainfall.

- Causes a slight variation of the peak flows from $-5 \%$ to + 5\% using Desbordes, Composite, Chicago, Triangular and Weibull structures.

- Does not affect the peak flows of the Uniform rainfall (Fig- 
ures 7A \& 7B).

However, the figure 8 showed that the variation of time step does not affect the hydrographs volumes calculated from the Uniform, Triangular, Desbordes, Composite and Weibull rainfalls. A slight change in the volumes of $2.5 \%$ to $7 \%$ has been recorded at the level of Watt rainfall, and of $2.5 \%$ to $5 \%$ at the level of Chicago storm for an increase of the step time from $100 \%$ to $200 \%$ of the reference value (Figures $8 \mathrm{~A} \& 8 \mathrm{~B}$ ).

\subsection{Peak Position}

The change of the peak position " $r$ " of the design rainfall structures was adopted on the basis of a reference position located in the middle of hyetograph (peak time is the product of " $r$ : peak position" and storm duration) with " $r=0.5$ ". Hence, the reference value varied from $-50 \%$ to $+50 \%$, which corresponds to an advanced rainfall $(r=0.25)$ and a delayed rainfall $(r=0.75)$, respectively. This variation neither affects the Desbordes rainfall structure nor the Uniform method. However, there is a structural change for the other types of design rainfall with lower rainfall intensities for the Weibull and Watt design rainfall. As for the Triangular, Composite and Chicago structures, the maximum intensities remain constant. The relative deviations of peak flows and runoff volumes for a variation of the Design storm peak position compared to the reference value according to the design rainfall structures selected are shown below (Figures 8 \& 9).

Based on these results (Figure 9A), we concluded that the structure of advanced rainfall ( $r=0.25$ ) generates:

- An increase of $+60 \%$ of the calculated peak flows on the basis of the Weibull rainfall and of $+10 \%$ of the Watt structure.
- A decrease of the peak flows of $-20 \%$ for the Chicago and Composite structures and of $-10 \%$ for the Triangular structure.

- In addition, the use of a delayed rainfall structure $(r=$ 0.75 ) causes (Figure 9B):

- An increase of the peak flows of $+20 \%$ for the Chicago rainfall and of $+10 \%$ for the Triangular method according to central position.

- A decrease of the peak flows of $-25 \%$ for the Weibull structure and of $-10 \%$ for the Watt structure.

Concerning the runoff volumes, the variation of the Design storm peak position relative to the middle hyetograph $(r=0.5)$ does not affect the volumes calculated from the different design storms (Figures 10A \& 10B) except for those of the Weibull rainfall. A decrease of $-7 \%$ of the volumes has been recorded for a delayed peak hyetograph $(r=0.75)$ compared to the central peak hyetograph (Figure 1OB).

\subsection{Use of the Principal Component Analysis Method}

The CPA is a data representation technique under certain algebraic and geometric criteria. Its objective is to extract most of the information in the data tables and to provide a simple and easy representation to interpret taking into account the correlations between different data (Dagnelie 1982).

The great advantage of this technique lays in its ability to deal simultaneously with a large amount of data. In addition, it allows the identification of the complex interrelationships existing between the variables, and the sum up or the briefs to a reduced number of indicators called factors or main components.

The implementation of the PCA algorithm on all the data us-

Table 5. Variances explained of components of peak flows and Design storm parameters.

\begin{tabular}{|c|c|c|c|c|c|c|c|c|c|}
\hline \multirow[b]{2}{*}{ Design storm } & \multirow[b]{2}{*}{ Proper Values } & \multicolumn{8}{|c|}{ Components } \\
\hline & & 1 & 2 & 3 & 4 & 5 & 6 & 7 & 8 \\
\hline & Total & 5.53 & 1.00 & 0.99 & 0.46 & 0.03 & 0.00 & 0.00 & 0.00 \\
\hline \multirow[t]{3}{*}{ Uniform } & $\%$ of variance & 69.15 & 12.50 & 12.34 & 5.69 & 0.31 & 0.01 & 0.00 & 0.00 \\
\hline & $\%$ accrued & 69.15 & 81.65 & 93.99 & 99.68 & 99.99 & 100.00 & 100.00 & 100.00 \\
\hline & Total & 5.90 & 1.15 & 0.89 & 0.06 & 0.00 & 0.00 & 0.00 & 0.00 \\
\hline \multirow[t]{3}{*}{ Triangular } & $\%$ of variance & 73.78 & 14.36 & 11.14 & 0.69 & 0.02 & 0.01 & 0.00 & 0.00 \\
\hline & $\%$ accrued & 73.78 & 88.14 & 99.28 & 99.97 & 99.99 & 100.00 & 100.00 & 100.00 \\
\hline & Total & 5.76 & 1.00 & 0.99 & 0.25 & 0.01 & 0.00 & 0.00 & 0.00 \\
\hline \multirow[t]{3}{*}{ Desbordes } & $\%$ of variance & 71.98 & 12.50 & 12.33 & 3.12 & 0.07 & 0.00 & 0.00 & 0.00 \\
\hline & $\%$ accrued & 71.98 & 84.48 & 96.81 & 99.93 & 100.00 & 100.00 & 100.00 & 100.00 \\
\hline & Total & 5.47 & 1.12 & 0.92 & 0.38 & 0.11 & 0.00 & 0.00 & 0.00 \\
\hline \multirow[t]{3}{*}{ Composite } & $\%$ of variance & 68.31 & 14.02 & 11.48 & 4.80 & 1.39 & 0.00 & 0.00 & 0.00 \\
\hline & $\%$ accrued & 68.31 & 82.33 & 93.81 & 98.61 & 100.00 & 100.00 & 100.00 & 100.00 \\
\hline & Total & 5.95 & 1.12 & 0.87 & 0.06 & 0.00 & 0.00 & 0.00 & 0.00 \\
\hline \multirow[t]{3}{*}{ Chicago } & $\%$ of variance & 74.31 & 14.02 & 10.88 & 0.78 & 0.02 & 0.00 & 0.00 & 0.00 \\
\hline & $\%$ accrued & 74.31 & 88.33 & 99.20 & 99.98 & 100.00 & 100.00 & 100.00 & 100.00 \\
\hline & Total & 5.83 & 1.16 & 0.85 & 0.16 & 0.00 & 0.00 & 0.00 & 0.00 \\
\hline \multirow[t]{3}{*}{ Weibull } & $\%$ of variance & 72.85 & 14.50 & 10.58 & 2.03 & 0.04 & 0.00 & 0.00 & 0.00 \\
\hline & $\%$ accrued & 72.85 & 87.35 & 97.93 & 99.96 & 100.00 & 100.00 & 100.00 & 100.00 \\
\hline & Total & -5.84 & 1.17 & 0.92 & 0.06 & 0.02 & 0.01 & 0.00 & 0.00 \\
\hline \multirow[t]{2}{*}{ Watt } & $\%$ of variance & 72.94 & 14.57 & 11.51 & 0.72 & 0.20 & 0.06 & 0.00 & 0.00 \\
\hline & $\%$ accrued & 72.94 & 87.51 & 99.02 & 99.74 & 99.94 & 100.00 & 100.00 & 100.00 \\
\hline
\end{tabular}



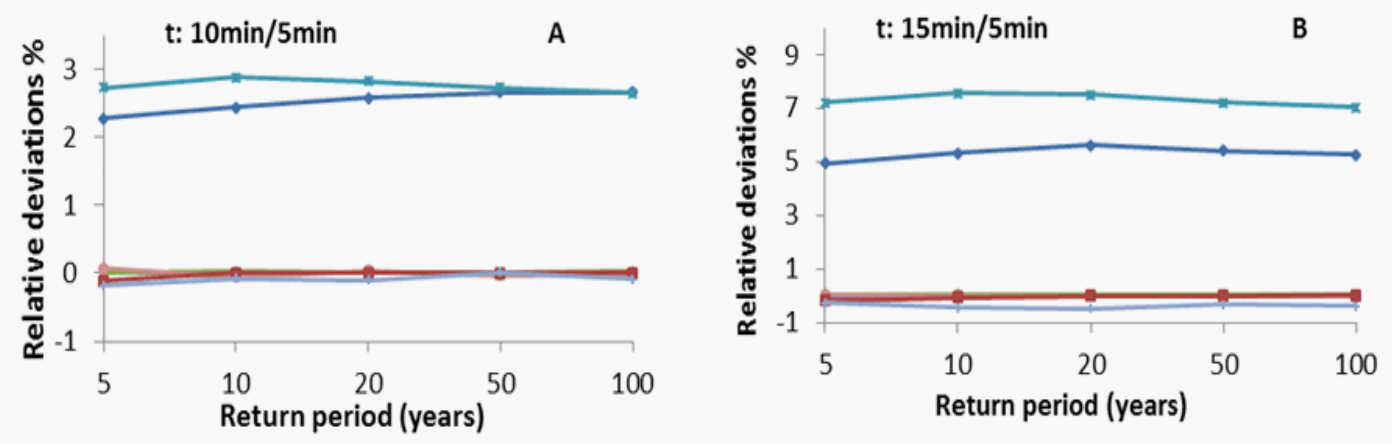

$\because$ UNIFORM $\multimap$ TRIANGULAR $\multimap$ DESBORDES

$\because$ COMPOSITE

$\rightarrow$ CHICAGO

WEIBULL

WATT

Figure 8. Relative deviations of runoff volumes for a variation of $+100 \%$ (A: $10 \mathrm{~min}$ ) and of $+200 \%$ (B: $15 \mathrm{~min}$ ) of time step reference (5 $\mathrm{min})$.

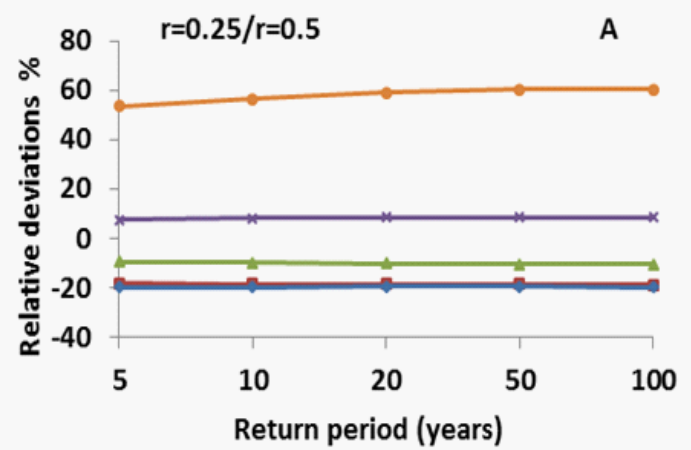

$\because$ TRIANGULAR

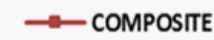

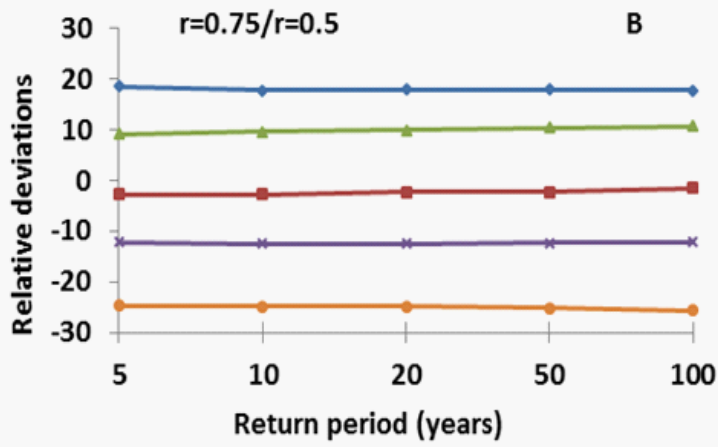

$\longrightarrow$ CHICAGO

$\longrightarrow$ Weibull

\#WATT

Figure 9. Relative deviations of peak flows for a variation of the Design storm peak position of $-50 \%(A)$ and of $+100 \%$ (B) compared to the reference value ( $r=0.5$ " middle of hyetograph").

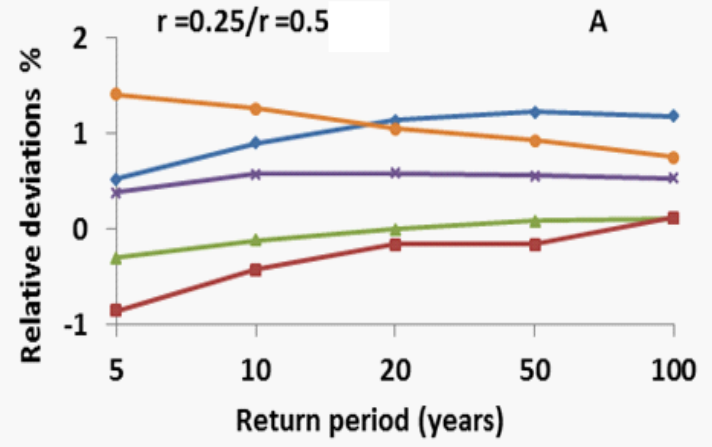

Return period (years)
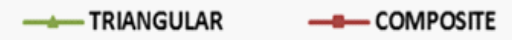

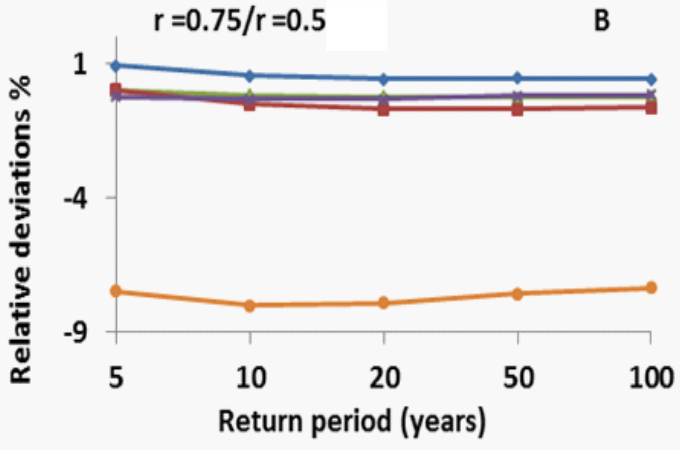

CHICAGO $\longrightarrow$ Weibull

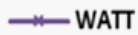

Figure 10. Relative deviations of runoff volumes for a variation of the Design storm peak position of $-50 \%$ $(A: r=0.25)$ and of $+100 \%(B: r=0.75)$ compared to the reference value $(r=0.5)$. 
Table 6. Variances explained of components of runoff volumes and Design storm parameters.

\begin{tabular}{|c|c|c|c|c|c|c|c|c|c|}
\hline \multirow[b]{2}{*}{ Design storm } & \multirow[b]{2}{*}{ proper values } & \multicolumn{8}{|c|}{ Components } \\
\hline & & 1 & 2 & 3 & 4 & 5 & 6 & 7 & 8 \\
\hline & Total & 6.03 & 1.00 & 0.96 & 0.00 & 0.00 & 0.00 & 0.00 & 0.00 \\
\hline \multirow[t]{3}{*}{ Uniform } & $\%$ of variance & 75.43 & 12.50 & 12.02 & 0.05 & 0.00 & 0.00 & 0.00 & 0.00 \\
\hline & $\%$ accrued & 75.43 & 87.93 & 99.95 & 100.00 & 100.00 & 100.00 & 100.00 & 100.00 \\
\hline & Total & 6.03 & 1.00 & 0.96 & 0.00 & 0.00 & 0.00 & 0.00 & 0.00 \\
\hline \multirow[t]{3}{*}{ Triangular } & $\%$ of variance & 75.43 & 12.50 & 12.02 & 0.05 & 0.00 & 0.00 & 0.00 & 0.00 \\
\hline & $\%$ accrued & 75.43 & 87.93 & 99.95 & 100.00 & 100.00 & 100.00 & 100.00 & 100.00 \\
\hline & Total & 6.03 & 1.00 & 0.96 & 0.00 & 0.00 & 0.00 & 0.00 & 0.00 \\
\hline \multirow[t]{3}{*}{ Desbordes } & $\%$ of variance & 75.43 & 12.50 & 12.01 & 0.05 & 0.00 & 0.00 & 0.00 & 0.00 \\
\hline & $\%$ accrued & 75.43 & 87.93 & 99.95 & 100.00 & 100.00 & 100.00 & 100.00 & 100.00 \\
\hline & Total & 6.03 & 1.00 & 0.96 & 0.00 & 0.00 & 0.00 & 0.00 & 0.00 \\
\hline \multirow[t]{3}{*}{ Composite } & $\%$ of variance & 75.43 & 12.50 & 12.01 & 0.05 & 0.00 & 0.00 & 0.00 & 0.00 \\
\hline & $\%$ accrued & 75.43 & 87.93 & 99.95 & 100.00 & 100.00 & 100.00 & 100.00 & 100.00 \\
\hline & Total & 6.05 & 1.00 & 0.94 & 0.00 & 0.00 & 0.00 & 0.00 & 0.00 \\
\hline \multirow[t]{3}{*}{ Chicago } & $\%$ of variance & 75.67 & 12.50 & 11.77 & 0.06 & 0.00 & 0.00 & 0.00 & 0.00 \\
\hline & $\%$ accrued & 75.67 & 88.17 & 99.94 & 100.00 & 100.00 & 100.00 & 100.00 & 100.00 \\
\hline & Total & 6.04 & 1.00 & 0.95 & 0.00 & 0.00 & 0.00 & 0.00 & 0.00 \\
\hline \multirow[t]{3}{*}{ Weibull } & $\%$ of variance & 75.46 & 12.55 & 11.93 & 0.04 & 0.01 & 0.00 & 0.00 & 0.00 \\
\hline & $\%$ accrued & 75.46 & 88.01 & 99.95 & 99.99 & 100.00 & 100.00 & 100.00 & 100.00 \\
\hline & Total & 6.06 & 1.00 & 0.93 & 0.00 & 0.00 & 0.00 & 0.00 & 0.00 \\
\hline \multirow[t]{2}{*}{ Watt } & $\%$ of variance & 75.78 & 12.50 & 11.68 & 0.04 & 0.00 & 0.00 & 0.00 & 0.00 \\
\hline & $\%$ accrued & 75.78 & 88.28 & 99.96 & 100.00 & 100.00 & 100.00 & 100.00 & 100.00 \\
\hline
\end{tabular}

Table 7. Matrix of components of peak flows and Design storm parameters.

\begin{tabular}{|c|c|c|c|c|c|c|c|c|c|c|c|c|}
\hline \multirow{2}{*}{$\begin{array}{l}\text { Design Storm } \\
\text { Components }\end{array}$} & \multirow{2}{*}{$\frac{\text { Uniform }}{1}$} & \multicolumn{2}{|c|}{ Triangular } & \multirow{2}{*}{$\begin{array}{c}\text { Desbordes } \\
1 \\
\end{array}$} & \multicolumn{2}{|c|}{ Composite } & \multicolumn{2}{|c|}{ Chicago } & \multicolumn{2}{|c|}{ Weibull } & \multicolumn{2}{|c|}{ Watt } \\
\hline & & 1 & 2 & & 1 & 2 & 1 & 2 & 1 & 2 & 1 & 2 \\
\hline Duration & -.909 & -.674 & .594 & .889 & .841 & .309 & .506 & .690 & .308 & .722 & -.353 & .793 \\
\hline Peak.position & .000 & .712 & .512 & .000 & .403 & -.696 & .824 & -.341 & -.875 & .230 & -.696 & .108 \\
\hline Q.100years & .992 & .993 & .102 & .986 & .985 & -.008 & .986 & .156 & .996 & -.018 & .997 & -.046 \\
\hline Q.50years & .996 & .997 & .071 & .991 & .986 & .019 & .982 & . 177 & .996 & -.055 & .992 & .009 \\
\hline Q.10years & .811 & .996 & -.007 & .998 & .986 & .077 & .977 & .205 & .997 & .021 & .996 & .016 \\
\hline Q.5years & .988 & .984 & -.115 & .998 & .827 & -.273 & .974 & .221 & .997 & .010 & .992 & -.010 \\
\hline
\end{tabular}

Table 8. Matrix of components of runoff volumes and Design storm parameters.

\begin{tabular}{|c|c|c|c|c|c|c|c|c|c|c|c|c|c|}
\hline \multirow{2}{*}{$\begin{array}{l}\text { Design Storm } \\
\text { Components }\end{array}$} & \multirow{2}{*}{$\begin{array}{c}\text { Uniform } \\
1\end{array}$} & \multicolumn{2}{|c|}{ Triangular } & \multicolumn{2}{|c|}{ Desbordes } & \multicolumn{2}{|c|}{ Composite } & \multicolumn{2}{|c|}{ Chicago } & \multicolumn{2}{|c|}{ Weibull } & \multicolumn{2}{|c|}{ Watt } \\
\hline & & 1 & 2 & 1 & 2 & 1 & 2 & 1 & 2 & 1 & 2 & 1 & 2 \\
\hline Duration & .997 & .997 & .001 & .998 & .001 & .998 & .002 & .992 & .003 & .994 & .059 & .990 & .005 \\
\hline Peak.position & .000 & -.001 & 1.00 & -.001 & 1.000 & -.002 & 1.00 & -.004 & 1.00 & -.078 & .961 & -.007 & 1.00 \\
\hline V.100years & .999 & .999 & -.002 & .999 & -.002 & .999 & -.005 & .999 & -.003 & .999 & .001 & .999 & .000 \\
\hline V.50years & .999 & .999 & -.002 & .999 & -.002 & .999 & -.005 & .999 & -.003 & .999 & -.002 & .999 & .000 \\
\hline V.10years & .999 & .999 & .001 & .999 & .001 & .999 & .001 & .999 & .000 & .999 & -.015 & 1.00 & -.002 \\
\hline V.5years & .999 & .999 & .004 & .999 & .004 & .999 & .011 & .999 & .008 & .999 & -.022 & 1.00 & .000 \\
\hline
\end{tabular}

ing the statistical software SPSS (IBM, 2012) gave intersting results (Tables 5-8).

Tables 5 and 6 show the main components which are 8, their initial values, the percentage of their variances, as well as the cumulative percentage of their variances. From these results, we observe that the first two components have eigenvalues greater than 1 and explain to them only about $85 \%$ of the total variance, so according to the Kaiser criterion which says that only components whose eigenvalues are greater than 1 should be kept (Yergeau.2013). So by keeping the first two components, 
we will have only $15 \%$ of information loss. The values indicated at the first line $(5.5,1.0 \ldots)$ of table 5 represent the eigenvalues of each component. The Total eigenvalues of each line is 8 , which is the number of studied variables (storm duration, step time, peak position and the peak flows for the five return periods). The tables 7 and 8 of the component matrices show information about the design storm parameters that influence the peak flows and the runoff volumes through the importance of the correlation coefficient (R). It concerns:

- The storm duration according to the following classification: the uniform rainfall ( $R=-0.909)$, the Desbordes rainfall ( $R$ $=0.889)$, the Composite rainfall $(R=0.841)$, the Triangular rainfall $(R=-0674)$ and the Chicago rainfall $(R=0.506)$. The variation of storm duration for Watt $(R=-0.353)$ and Weibull structures $(R=0.308)$ does not significantly affect the peak flows.

- The time step simply for the Watt rainfall $(R=0.526)$. The change of this parameter for other design storms has an insignificant impact on the peak flows $(R<|0.5|)$.

- The peak position for Weibull rainfall $(R=-0.875)$, Chicago rainfall $(R=0.824)$, Triangular rainfall $(R=0.712)$ and Watt rainfall $(R=-0.696)$. The change of the peak position for Composite rainfall $(R=0.403)$ has a low impact on the peak flows. However, the peak flows generated from Uniform and Desbordes storms have not been affected by the change of the position of the storm peak.

Concerning runoff volumes, the PCA method showed that only the storm duration that influences runoff volumes as shown in the table above. Indeed, there is a high correlation of the storm duration with the principal component 1 ( $R>0.9)$. This component is reconstructed by runoff volumes for five return periods ( $T=5$, $10,20,50$ and 100 years). PCA results concure with the sensitivity analysis results. Specifically:

- The storm duration affects peak flows for the Uniform, Desbordes, Composite, triangular and Chicago structures.

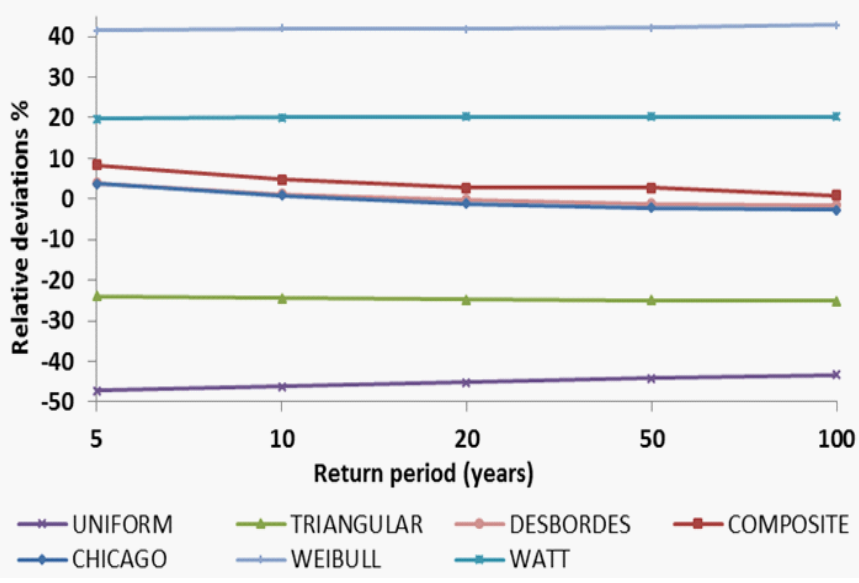

Figure 11. Comparison of relative deviations peak flows generated from design rainfall structures compared to synthetic rainfall.
- The time step influences the peak flows for the Watt structures.

- The peak position impacts the generated peak flows by the Weibull, Chicago, Triangular and Watt design storms.

- The runoff volumes are influenced only by the storm duration.

\subsection{Selection of the Design Rainfall Structure}

With the aim to select the design storm that adapts to our study area, we analyzed the rainfall data of the Tangiers experimental basin to determine the structure of the average storm of which the generated peak flows have been compared to those established on the basis of the different design rainfall structures above (Figure 11). Figure 11 clearly shows that the Desbordes, Chicago and composite rainfalls allow the determination of peak flows with minor deviations in relation to the generated peak flows based on the observed synthetic rainfall structure.

For the other types of design rainfall structures, the Uniform and Triangular rainfall underestimated the SWMM model peak flows with variations of $-45 \%$ and $-25 \%$, respectively. Moreover, the Weibull and Watt structure over-estimated peak flows with respective variations of $+40 \%$ and $+20 \%$. The same comparison has been made for the selection of the SCS synthetic storm of which structure is similar to that of the observed synthetic rainfall. The SCS method type 1 is the closest structure of the synthetic rainfall of the observed events in the Tangiers experimental basin (Figure 12).

\subsection{Weibull and Watt Design Rainfall Calibration}

The design storms that have been calibrated are those with other empirical parameters whose values are specific to the study area. It concerns the " $n$ " form parameter of the Weibull

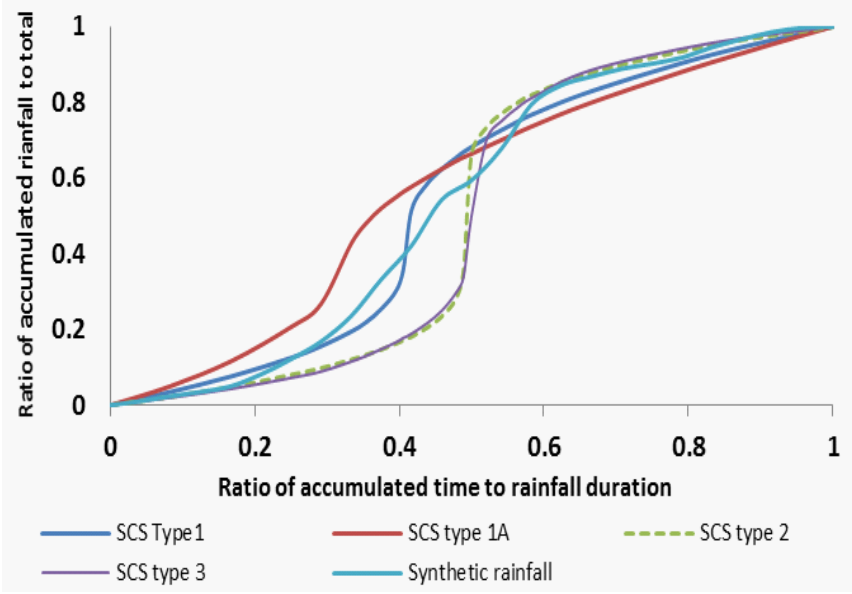

Figure 12. Comparison of the structures of the rainfall types SCS against to the observed synthetic rain. 
design rainfall and the "K" decay coefficient for Watt rainfall. The parameters values to be maintained are those which permit to have the peak flows comparable to those determined from the synthetic rainfall of observed events in the Tangiers experimental basin.

A comparison of the peak flows for the Watt and Weibull structures for the various parameter values has been established in order to select the range of values to be used for calibration. The selected values were between 4 and 5 for the $\mathrm{K}$ parameter of the Watt rainfall, and between

10 and 15 for the $\mathrm{n}$ parameter of the Weibull rainfall (Figure 13).

Thus, the form parameter values resulting from calibration are:

- $K=4$ for Watt rainfall structure

- $\mathrm{n}=12$ for Weibull rainfall structure

These values allow us to generate peak flows from the SWMM model comparable to peak flows from the observed synthetic as well as Desbordes rainfall structures (Figure 14).

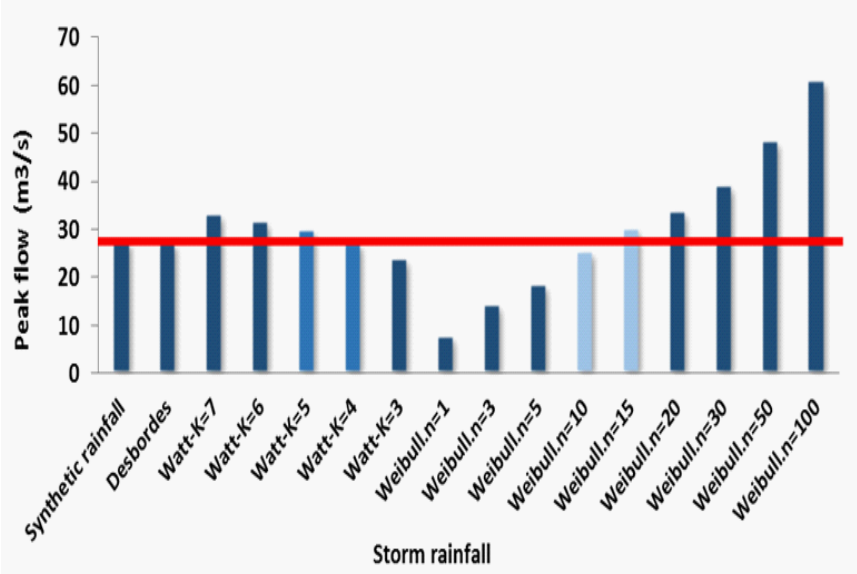

Figure 13. Comparison of peak flows calculated using various forms of Weibull and Watt rainfall structures.

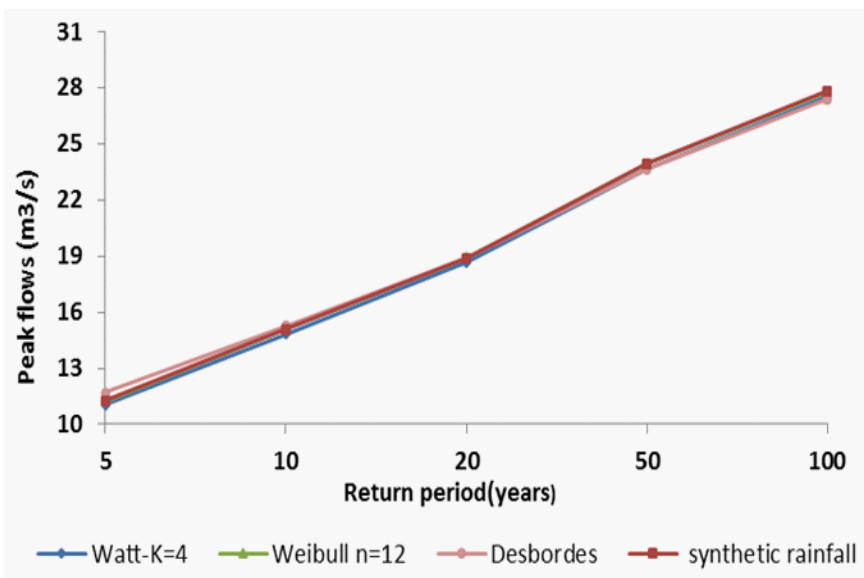

Figure 14. Calibration of the design rainfall of Weibull and Watt compared to the structure of the synthetic rain and Desbordes.

\section{Conclusions}

The comparison of different design rainfall structures has led to the conclusion that the peak flows are not necessarily affected by the value of the considered maximum intensity, but rather by the rainfall structure that plays an important role in the determination of the peak flows generated. To further advance our analysis, a study of the Storm Water Management Model (SWMM Version 5.0.022-US EPA, 2011) model sensitivity to various design rainfall structures parameters was performed. The parameters studied include the storm duration, time step, and the peak hydrograph position.

The study of the SWMM model sensitivity in relation to the types and parameters of design rainfall structures derived from IDF curves showed that:

- The storm duration affects peak flows for the Uniform, Desbordes, Composite, triangular and Chicago structures.

- The time step influences the peak flows for the Watt structures.

- The peak position impacts the generated peak flows by the Weibull, Chicago, Triangular and Watt design storms.

- The runoff volumes are influenced only by the storm duration.

PCA results concur with the conclusions based on the sensitivity analysis results discussed above.

Comparison of peak flows from the different types of design rainfalls with those calculated from the synthetic rainfall of the observed events in the Tangiers experimental basin confirmed that the Desbordres, Chicago and composite structures best fitted observed events. Moreover, comparison between the synthetic rainfall structure of the observed events and the SCS rainfall structures types allowed us to select the SCS synthetic type 1. Calibration of the Weibull and Watt design rainfall structures compared with the synthetic rainfall of the observed events suggested that parameters values of 4 and 12 for the Watt rainfall and Weibull rainfall structures, respectively.

\section{References}

ADM (2008) Elaboration des standards d'ADM en Assainissement, Analyse critique et méthodologies, 52p.

Musy A and C Higy (1998) Hydrologie Appliquée, Ecole Polytechnique Fédérale de Lausanne, Institut d'Aménagement des Terres et des Eaux, Hydrologie et Aménagements. GR Ecublens CH, 1015 Lausanne, Suisse, $365 \mathrm{p}$.

Bennani Baiti H, A Bouziane, D Ouazar, and MD Hasnaoui (2017) Etude de sensibilité des paramètres du modèle de transformation pluie débit SWMM. Cas du bassin expérimental de la ville de Tanger, la houille blanche 1: 1-9.

Bourrier R (1981) Les réseaux d'.assainissement : calculs, applications et perspectives, Paris, Editions Techniques et Documentation, $298 \mathrm{p}$.

Bouziane A and BH Bennani (2013) Bassins versants expérimentaux : études des événements pluies-débits, Equipement d'un bassin expérimental urbain, Livrable $n^{\circ} 2$ : Description et présentation des équipements du bassin expérimental et leurs modes de manipulation, EMI, Rabat, p. 50.

Chocat B (dir.) (1997) Encyclopédie de l'Hydrologie Urbaine et de l'Assainissement (Eurydice 92, Coordination B. Chocat). Editions Tec 
et Doc, Lavoisier, Paris, 1136 p.

Chow VT, DR Maidment, and LW Mays (1988) Applied Hydrology, Urbana-Charnpaign, Illinois, McGraw-Hill, 572 p.

Corinne Hahn, Sandrine Macé (2012) Méthodes statistiques appliquées au management, Pearson Education France, 342 p.

Dang TD (1999) A surface water drainage model for Hanoi, Master Thesis, Hanoi (in Vietnamese).

Dagnelie A (1982) Analyse statistique multivariée, Edition de Gembloux, pp. 320.

Hager WH and RO Sinniger (1988) Reservoir storage effect on design flood. Proc Seizième Congrès des Grands Barrages. San Francisco Q.63-R. 80: 1375-1399.

Hoang LV (1987) Drainage planning for the Thiep river basin, Technical report, The Water Resources University, Hanoi (in Vietnamese).

Huff FA (1967) Time distribution of rainfall in heavy storms. Water Resources. Res 3 (4): 1007-1019.

IBM (2012) Statistical Package for the Social Sciences [En ligne], SPSS inc, www.ibm.com/software/analytics/spss/products/statistics/index.html.

INGEMA (2001) Etude de réévaluation du potentiel des ressources en eau superficielles des bassins de la zone d'action de l'Agence du Bassin Hydraulique du Loukkos, Mission 1, l'analyse critique des données pluviométriques, l'élaboration des séries pluviométriques, l'établissement des cartes isohyètes et la détermination des courbes Intensités -Durées - Fréquences, 143 p.

Keifer $\mathrm{CJ}$ and $\mathrm{HH}$ Chu (1957) Synthetic storm pattern for drainage design. J. Hyd 83 (HY4): 1-25.

Meylan P, AC Favre, and A Musy (2012) Predictive hydrology. A frequency Analysis Approach, CRC Press, Boca Raton, p. 180.
Mitci C (1974) Sur une nouvelle méthode de calcul des débits d'orage et des hydrogrammes de ruissellement dans les bassins de drainage urbain. TSM (2) : 59-74.

ONEP (1998) Direction de l'eau et de l'assainissement, Schéma Directeur National d'Assainissement Liquide, mission II, Sous mission II.3, Méthodes d'évaluation des débits à évacuer, p. 160.

Pilgrim DH and I Cordery (1975) Rainfall temporal patterns for design floods. J. Hyd. Div, Am. Soc. Civ. Eng 101( HY1): 81-95.

Rakik $A$ and M Eijelouli (1994) Réflexions sur les méthodes d'évaluation des débits pluviaux en zones urbaines Projet de fin d'études, EMI, Rabat.

Soil Conservation Service (1986) Urban Hydrology for small Watersheds, Second edition, Tech. Release No.20, Washington, D.C., U.S. Department of Argiculture.

Thang NN (2005) The scientific basis for the operation of detention ponds for the To Lich basin, Hanoi, Master Thesis, Hanoi (in Vietnamese).

US Environmental Protection Agency (2011) Storm Water Management Model (SWMM), Version 5.0.22 [Software]. Available from http:// www.epa.gov/ednnrmrl/ models/swmm.

Watt WE, KCA Chow, WD Hogg, and KW Lathem (1986) A 1 -H Urban Design Storm for Canada. Canadian Journal of Civil Engineering (13): 293-300.

Yen BC and VT Chow (1980) Design hyetographs for small drainage structures. Journal of the Hydraulics Division. American Society of Civil Engineers 106 (HY6): 1055-1076.

Yergeau E and M Poirier (2013) SPSS à l'UdeS. URL: <http://spss. espaceweb.usherbrooke.ca $>$. 